Western University Scholarship@Western

Centre for the Study of International Economic

Centre for the Study of International Economic

Relations Working Papers

Relations

1980

\title{
Free Trade between the United States and Canada: Fifteen Years Later
}

Paul Wonnacott

Ronald J. Wonnacott

Follow this and additional works at: https://ir.lib.uwo.ca/economicscsier_wp

Part of the Economics Commons

Citation of this paper:

Wonnacott, Paul, Ronald J. Wonnacott. "Free Trade between the United States and Canada: Fifteen Years Later." Centre for the Study of International Economic Relations Working Papers, 8011. London, ON: Department of Economics, University of Western Ontario (1980). 
CENTRE FOR THE STUDY OF INTERNATIONAL ECONOMIC RELATIONS

WORKING PAPER NO. 8011

Paul Wonnacott

and

Ronald J. Wonnacott

This paper contains preliminary findings from research work still in progress and should not be quoted without prior approval of the author.

DEPARTMENT OF ECONOMICS

UNIVERSITY OF WESTERN ONTARIO

LONDON, CANADA

N6A 5 C2 


\title{
FREE TRADE BETWEEN THE UNITED STATES AND
}

\section{CANADA: FIFTEEN YEARS LATER}

\author{
by \\ Paul Wonnacott \\ and. \\ Ronald J. Wonnacott
}

March, 1980 
I. A SUMMARY OF OUR EARLIER CONCLUSIONS

II. IMPORTANT CHANGES IN THE PAST DECADE AND A HALF

1. The Growth of Industrial Power Outside North America 10

2. Changes in the World Trading Environment 12

3. Natural Resources

4. Changes in the Relative Industrial Position of Canada and the United States: Real Variables

5. Changes in Canada-U.S. Monetary Variables (Wage Difference and Exchange Rate)

III. A RESPONSE TO CRITICS

1. Out-of-Date?

2. Textbook Assumptions?

3. Bilateral Free Trade Dominated by Multilateral or Unilateral Reductions in Trade Barriers?

4. Can the EEC be considered a precedent? Isn't North America quite different from Europe?

5. Adjustment Too Painful?

6. Will Free Trade Leave Canadian Industry Truncated?

7. A Criticism the Critics Missed

IV . CONCLUSIONS 
One objective of our 1967 study was to provide a solid base of analysis and factual data for the recurrent discussion of free trade between Canada and the United States--the "Issue that Won't Die," in the words of one newsman. By and large, we believe that this objective has been achieved. While substantial differences of opinion of course remain on a matter of such importance and complexity, the discussion of free trade in the past decade has been carried on in a serious manner, with the ratio of analysis to rhetoric being much higher than in previous eras (such as the early part of the century, when reciprocity was rejected with the slogan, "No truck or trade with the Yankees"). And, with the more serious discussion of trade issues has come a movement in the center of Canadian opinion. No longer is the idea of free trade with the United States considered the quaint idea of a few academic scribblers; it is now viewed as a serious option. Reflecting such a change in opinion, the Globe and Mail (in a July 13, 1979 editorial that reiterated its traditional view that we are not yet ready for CanadaUnited States free trade) nonetheless conceded a thought unthinkable 15 years before :

In a world where free trade areas are rapidly growing and demonstrating global strength, it is reasonable that one of them, eventually, should join Canada and the United States. 
Much of this shift in opinion away from traditional protection and towards some form of more liberalized trade has been attributable to two studies from Ottawa--the Economic Council's 1975 report, Looking Outward, and the 1978 study of Canada's Trade Relations with the United States by the Standing Senate Committee on Foreign Affairs. Both have greatly expanded our understanding of the implications of trade liberalization. The purpose of this paper is to update parts of our earlier study, and to answer our critics. [Considerable initial updating was done in Wonnacott (1975) where we dealt in detail with the question, "Didn't the elimination at that time of the traditional wage gap between Canada and the United States reduce or eliminate the gains from free trade?"--an issue to which we return below.] The present paper is divided into three parts: A brief summary of our principal earlier conclusions; a discussion of how developments during the past dozen years have affected these conclusions; and a response to our critics.

\section{A SUMMARY OF OUR EARLIER CONCLUSIONS}

Our starting point was the work of English (1964) and others on the relationship between Canadian industrial organization and protection. Specifically, one of the major drags on efficiency has been the tendency for Canadian manufacturers--whether domestically-owned or subsidiaries of foreign corporations--to produce a wide variety of products for the small Canadian market. Firms in Canada achieve fewer economies of scale than in the United States, not so much because Canadian plants are smal1, but because individual plants do not specialize. 
In our 1967 book, we foresaw a number of results from a bilateral free trade arrangement:

1) Canada would reap substantial benefits from more efficient; large-scale production. Much of the specialization would take place within industries, and, indeed, within plants. For example, a canadian automotive plant would produce a relatively few models, with most of the Canadian production being exported to the United States in exchange for other models. (This specialization was beginning to occur as our book was being finished, as a result of the Automotive Agreement of 1965.) This specialization within industries would cause less disruption than the inter-industry specialization foreseen by traditional constant-returnsto-scale trade models. At the same time it would tend to yield much higher benefits, since gains would come from a fall in costs per unit of output, and would not be confined to the relatively small triangular gains estimated in previous empirical studies. ${ }^{1}$ (These studies assumed rising or flat supply curves, and did not capture the benefits from economies of scale.)

2) Canadian industry located in Southern Ontario and Quebec would face only minor (non-wage) cost disadvantages compared to the core of U.S. industry in the "golden triangle" formed by Chicago, Boston, and Baltimore. Indeed, Southern Ontario industrial locations are very close to this area, and face only a modest disadvantage in terms of transport

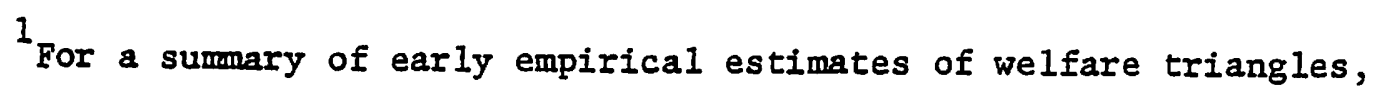
see Harvey Leibenstein (1966), pp. 392-397. 
costs, capital costs, etc. This meant that, with free trade it would be possible not only for Canadian (pre-tax) product prices to fall close to the U.S. level, but it would also be possible after an extended period of adjustment for the Canadian wage rate to rise to a level somewhat below that prevaling in the golden triangle; that is, to a level about as high as the U.S. average. ${ }^{1}$ [Whereas Southern Ontario faced some modest (non-wage) cost disadvantage vis-à-vis the golden triangle, it enjoyed an advantage vis-à-vis most other U.S. regions.]

With the substantial reduction of wage and (pre-tax) price differences between Southern Ontario and the Northeastern U.S. industrial triangle, the benefits to Canada of free trade with the United States would be large; we estimated long-term benefits between

${ }^{1}$ our favorable conclusion on rising wages would not have followed had Canadian labor been inferior to U.S. labor in terms of skills, work attitudes, etc. But available evidence suggested that this was not the case; see, Wonnacott and Wonnacott (1967), pp. 37-42. 
7 and $10.5 \%$ of Canadian GNP, ${ }^{1}$ although by 1975 this was scaled down somewhat for reasons detailed below.

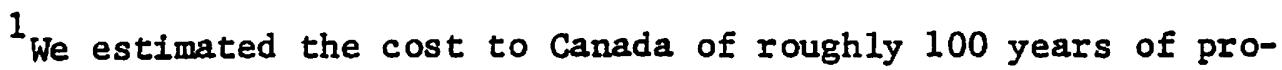
tection by both countries to be approximately $10.5 \%$ of GNP, a figure which has been frequently quoted. However, we emphasized that these costs could not be recouped quickly, because of "numerous impediments and imperfections." Therefore the estimated long-term benefițs were placed in the $7-10.5 \%$ range (Wonnacott and Wonnacott (1967), p. 300.)

Because some of the potential free trade gains have been realized since as a result of the Kennedy Round of tariff cuts and the Auto Pact (see especially the footnote on p. 27 below) the remaining gains from free trade are less than they otherwise would have been. But this does not weaken the general case for freer international trade; rather it illustrates the gains. Indeed, there are grounds for believing that, without the improved access to foreign markets, Canada's relative position in manufacturing might have declined vis-à-vis the United States. If anything, economies of scale (defined broadly, to include the effects of overhead costs associated with technological change) seem to be getting more important as time passes. This is perhaps most obvious in the automobile industry, where the combined pressures for pollution control and fuel economy have greatly increased capital needs, 
3) What would be the gains from free trade for the United States? Because producers in many U.S. industries had already captured most available economies of scale, the gains to the United States might be Iittle more than the efficiency triangles of traditional international trade theory. ${ }^{1}$ Therefore the gains to the United States seemed likely to be smaller in absolute terms than the gains to Canada, and accordingly much

Footnote (cont ${ }^{\mathrm{d}}$.)

leaving smaller companies in very precarious positions. In the absence of the 1965 Auto Agreement which gave access to the U.S. market, the Canadian industry might have had difficulty surviving unless tariff barriers had been increased (although this isn't absolutely clear without knowing what pollution and mileage regulations might have been imposed in a separate Canadian market). Thus the Auto Pact not only provided the benefits of increased productivity, but. may have allowed us to avoid the costs of the alternative option of increased protection.

${ }^{1}$ It is sometimes casually assumed that economies of scale are unimportant as a source of U.S. gain from trade because of the size of the U.S. market. This is not so in all industries, however. In a number of products (e.g., commercial aircraft) exports provide a significant opportunity for the United States to reduce its costs per unit. But it is the world market, and not just the Canadian market, which is relevant here; the scale benefits to the United States from a free trade arrangement with Canada are unlikely to compare to those available to Canada. 
There are two other reasons for a heavy incidence on Canada of the U.S. tariff: First, existing U.S. tariffs prevent some Canadian producers with falling costs from penetrating the U.S. market. Consequently, they are unable to get their costs down by exploiting economies of scale. Second, even if the U.S. tariff.is not prohibitive-indeed, even if the U.S. tariff is at a very. low level--fear of a future increase in that tariff may deter Canadian industry from undertaking the reorganization costs necessary to scale up for the North American market. In other words, for Canada to reap maximum gains, there would have to be a commitment on the U.S. part to keep tariff (and other barriers) down.

5) Whereas substantial Canadian gains from higher-volume production might be achieved by specialization and trade, these gains could not be achieved by concentration on the domestic economy alone without incurring other costs. To illustrate: Suppose Canadian production of refrigerators were to be rationalized (and economies of scale captured) by having only one model produced on a long production line. This would involve two costs: Canadian consumers would find their choice limited, and the Canadian economy would become increasingly monopolized. But international trade provides hope for dealing with this economies of scale/monopoly dilemma-a point that recurs in the Report of the Royal Comission on Corporate Concentration (1978). With free trade, large-scale production can be achieved, with much of the production being exported. At the same time, increased imports provide Canadians with wider choice among products, and insulation against monopoly abuse. ${ }^{1}$

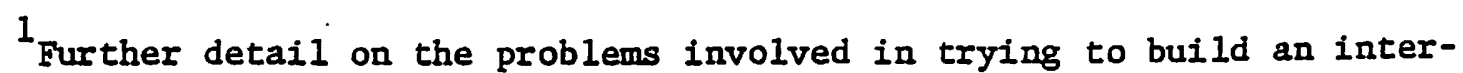
nationally competitive industry by concentrating on a relatively small, protected domestic market may be found in Wonnacott (1975b). 
II. IMPORTANT CHANGES IN THE PAST DECADE AND A HAIF

Since our book was published, significant changes, have occurred in the data and institutional background on which we based our study. For example, a number of the factors influencing Canada's competitive position vis-a-vis the United States have changed. In particular, substantial changes have occurred in the labour productivity-wage-exchange rate nexus; in addition, there has been a slow drift in the center of gravity of U.S. industry and population to the south and west, away from the Canadian industrial heartland.

Moreover, the competitive position of Canada and the United States vis-a-vis third countries has also changed. Stronger competition is now felt, both from the old developed countries of Europe and Japan, and from vigorous new industrial economies such as those of Brazil, Korea, and Taiwan; the international economic game is no longer played so predominantly in the American court. Finally, there have been substantial changes in the world trading environment. Access to raw materials (especially oil) has taken on new significance. Tariff barriers have been reduced as a result of GATT negotiations; and it is not yet clear to what degree they are being replaced by non-tariff controls.

In examining how the case for bilateral free trade has been affected, we first consider several background, worldwide changes, and then turn to two important changes that have occurred within North America. 


\section{The Growth of Industrlal Power Outs1de North America}

For a number of reasons the relative posttion of both Canada and the United States in the Industrial world has declined. New Industrial centers In Braz11 and Korea have emerged; and. Japanese growth has been substantially more rapld than ours (see Table 1).. Clearly, our relative decline is not all bad; when emerglng countries raise their relative positions, the relative positions of some other country or countrles must of necessity fa11. And the development of the poorer countrles is a welcome event.

\section{Table 1}

Real Economic Growth in the Industrialized World

$\begin{array}{lccc} & 1960-70 & 1970-80 & 1980-90 \text { (est.) } \\ \text { Japan and Oceania } & 9.4 \% & 5.1 & 5.0 \\ \text { North America } & 4.0 & 3.3 & 3.1 \\ \quad \text { Europe } & 4.7 & .2 .9 & 3.5\end{array}$

Sources: 1960-80, World Bank, World Development Report (New York: Oxford Unfversity Press, 1979); 1980-90, National Planning Assoclation estimates.

The growth of industrial power outside North. America seems to have increased the benefits to Canada of a free trade area with the United States in some respects, and increased its cost in others. On the benefit side, the preference vis-a-vis third country producers that Canadian exporters would enjoy in the U.S. market has become more valuable as third country competition has become more intense. But just as this benefit to Canada of U.S. trade diversion in our favor has been heightened, so has the cost to Canada of our own diversion: Because of 
preference we would be granting U.S. goods, we would be switchlng our purchases of some products to the Unfted States from the cheapest source of world supply in third countrles. And since 1967, third countries have become the cheapest source of supply in a variety of new products. 1 On balance, our view is that the growing economic power of third countries has strengthened the case for avoiding an inward-looking North American market; we have too much to gain from trade with the rest of the world. Increasingly, any bilateral arrangement should. be seen as a complement to, rather than as a substitute for, multilateral trade liberalization. [The Economic Council (1975, p. 104) placed bilateral free trade with the United States as the fourth ranked option, well behind multilateral trade liberalization, and also behind free trade areas with either the United States and Europe, or with the United States and Japan. ]

This point should not be overstated: With the realignment of currencies, foreign suppliers have lost some of their cost advantages. 


\section{Changes in the World Trading Environment}

With the multilateral reduction of tariffs from the Kennedy and Tokyo Rounds, should not Canada have somewhat better access to world markets for industrial products even in the absence of a special arrangement with the United States?

One hopes that the answer is: yes. But at this point we can't be sure. While tariffs have come down, the 70 's has been a decade of increasing non-tariff barriers and "managed" trade. In the Tokyo Round, progress was made in dealing with NTB's, as well as tariffs. As a consequence, this Round seems to have been successful, at least in the sense that trade will be more liberal than it would otherwise have been. But at the same time these negotiations may prove to have been primarily a "damage limitation exercise" kept the world trading environment from deteriorating. From the Canadian point of view it is still impossible to pass judgment on this issue, since the success of the Tokyo Round cannot be assessed until we see how some of its clauses (involving such ambiguous adjectives as "reasonable" and "material") are to be interpreted by our trading partners.

\footnotetext{
${ }^{1}$ In the words of former U.S. Deputy Special Trade Representative
} Harald Malmgren, as quoted by Hobart Rowen in the Washington Post, June 14, 1979. 
The drift towards "managed trade" in the 70's has had 1mportant implications for Canada. (Were it not for this--were tariffs the only remaining barriers to trade--it might appear that we were moving rapidly towards free access to the U.S. market: Within the next 8 years, $80 \%$ of Canada's exports will be entering the United States duty free. ${ }^{1}$ )

If the post-Tokyo world is one of lower tariffs, but not substantially less managed trade (in other words, if the Tokyo Round only slows or stops the growth of NTB's, but does not reverse it) many Canadian producers may . feel that they face the disadvantages of liberalized trade without its advantages. [Canadian barriers (tariffs) have been reduced, ${ }^{2}$ but foreign barriers (NTB's) have not.] The problem therefore for Canada may increasingly be how to "get behind" foreign (especially the United States) administrative walls (Grey, 1979). Even if a new GATT round were in prospect, it is unlikely that it would provide Canada with much leverage in this regard; given the tendency of the big powers to concentrate on negotiating with one another, Canadian gains tend to be limited to "piggyback benefits" negotiated by the

$1^{1}$ of course, this is not as close to free access as it seems, because of the well-known bias in any tariff average. (If half a nation's potential exports are duty free, and the other half face a prohibitive foreign tariff, then $100 \%$ of its actual exports will be duty free. This biased figure makes it seem like this nation is trading freely, but it is not.)

2 We emphasize: This is a disadvantage for Canadian import-competing producers, but not for the nation as a whole. 
with the United States (either on an across-the-board or an industry basis). This would provide not only a better prospect of dealing with U.S. NTB's, but also a better guarantee that U.S. barriers, once lowered, will not be raised again. In short, while multilateral free trade would still, in all likelihood, be more beneficial for Canada than bilateral free trade with the United States, ${ }^{1}$ it would be far more difficult to negotiate in a meaningful way.

To be realistic, it is hard to see how--short of out-and-out political union--Canada can hope to achieve complete success in getting behind the entire U.S. administrative wall; there will always be a residual trading cost associated with the maintenance of a Canadian national identity ${ }^{2}$-one which we believe Canadians are more than willing to pay. But partial success might be feasible, and yield substantial gains. (For example, in 1971 when

${ }^{1}$ This is a probable outcome, but not a certain one: It is theoretically possible for the benefits of U.S. trade diversion in our favor to be sufficient to make Canadians economically better off with a bilateral arrangement with the United States.

${ }^{2}$ Although there is some residual economic cost in the form of trading barriers that cannot be expected to fall to zero between separate political entities, Canadians do not necessarily pay a net economic cost for their political independence. Indeed, it is quite possible that any gains in reducing residual barriers by moving from free trade to political union would be overshadowed by net losses on natural resource rents, or by the costs of contributing to the U.S. military budget. Furthermore, even political union would not completely eliminate trade barriers; some exist between U.S. states.) 
President Nixon imposed tariff surcharges on dutiable imports, the Auto Pact allowed the Canadian industry to retain its duty-free access. into the U.S. market. Thus our auto industry enjoyed not only the benefit of continued duty-free access to the U.S. market, but found in addition that its access to the U.S market was on even more attractive terms than before because competition from third countries was temporarily reduced.)

\section{Natura1 Resources}

One of the most spectacular changes in the world trading environment: In the past decade has been the skyrocketing price of oil. Indeed, it is hard to belleve that only a decade ago Canada was anxious to sell more oll to the Onfted States than the Informal U.S. 1mport quota then allowed--and at a price only about $10 \%$ as high as the present price. Now, of course, the overwhelming concern is how to find sources of ofl, not markets for 1t. This is also true of Canada, which is no longer a surplus country.

In such changing circumstances, it is not clear how energy would be'dealt with in any free trade discussions. It would be quite out of the question simply to include energy in a free-trade agreement, because the governments in each country have become so deeply involved in regulating price and allocation. An unimpeded flow across the border would not be permbsible because of the way it would undercut domestic price regulations and redistribute income. Furthermore, glven exfsting domestic regulations, it is far from clear that freer flows of energy would even contribute to economic efflctency. 
Consequently, energy like agriculture cannot be included in any straightforward free trade arrangement. ${ }^{1}$ Nonetheless, energy still might be included in the negotiation of free trade in other sectors; indeed, it now seems likely that the United States would press for at least some Canadian commitment of future energy supplies. This does not mean that Canada should engage in a natural resource giveaway to "bribe" the United States into an industrial free trade arrangement. But it does mean that Canada would have to consider what, if any, assurances regarding supplies of oil or gas it would be willing to provide the United States as part of any general agreement. Such assurances might involve little cost to Canada, even though they would be welcomed by the United States; for example, an assurance by Canada of future sales to the U.S. of natural gas that we would plan to export anyway-at the then-prevailing world price. Such an assurance might be of substantial value to the United States simply because it would reduce uncertainty in a world of high energy risks. And just as Canada might assist the United States in reducing its energy risk, the United States might as a quid pro quo concede a reduction in Canada's risk as trade is liberalized--by, for example, agreeing to a more rapid reduction in the U.S. than the Canadian tariff, and by accepting special temporary measures (detailed below) to buffer and encourage Canadian industry during the period of adjustment. (We find this idea of trading risk an interesting variant on the more general observation that trade negotiations are generally not a zero sum game. In this case, each country may be in a position, with little cost to itself, to offer the other a valuable means of reducing risk.)

\footnotetext{
${ }^{1}$ For further detail on this issue, see The Economic Council of Canada (1975, Ch. 12).
} 
As a final observation, the idea of liberalized trade with the

Unt ted States has sometimes been dismissed as a non-starter because the Onited states would not be interested. With the energy developments in. the last decade, this criticlsm--never a particularly strong one (Wonnacott, 1975, p. 105)--has disappeared altogether. When Canada talks, the Untted States w111 listen.

In the final two sections, we turn to the changes that have occurred whin North Amerlca that may have altered Canada's ability to compete with the United States.

4. Changes in the Relative Industrial Position of Canada and the United States: Real Variables

The last 13 years have brought some favorable developments for Canada, and some unfavorable ones. On the unfavorable side, Table 2 1llustrates the recent (and projected) southwesterly drift of U.S. economic activity. This means that Ontario and ouebec. are geographically in a relatively less strong position for reaping advantages of free trade than a decade ago. However, the main

\section{Table 2}

Reglonal Drift in U.S. Economlc Act1v1ty: Distribution of Personal Income

\begin{tabular}{lrrrrr} 
& 1960 & $\underline{1970}$ & $\underline{1979}$ & $\frac{1990}{5}$ (proj.) \\
New England & $6.4 \%$ & $6.3 \%$ & $5.7 \%$ & $5.5 \%$ \\
Middle Atlantic & 24.8 & 23.5 & 21.1 & 20.1 \\
Great Lakes & 21.7 & 20.6 & 19.7 & 18.7 \\
Southeast & 15.8 & 17.7 & 20.3 & 21.5 \\
Plains & 7.9 & 7.6 & 7.5 & 7.3 \\
Southwest & 6.9 & 7.3 & 8.4 & 8.7 \\
Mountains & 2.3 & 2.2 & 2.6 & 3.0 \\
Far West & 14.1 & 14.7 & 14.7 & 15.2 \\
\hline
\end{tabular}

Source: National Planning Association, Regional Economic Projections Series (Washington, 1979). 
center of 1rdustry and 1ncome still remains in the northeastern quadrant of the Untted States, and is st1ll large enough to provide Canadian locations with substantial economies of scale. One way of viewing this drift is that an Ontarịo Industry that in 1967 would have found 1ts market expanded by say $500 \%$ by free access to U.S. markets, would now (and for some time into the foreseeable future) find its market expanded by something over $400 \%$ 1nstead. The gains from speciallzation and scale would not be greatly diluted. Another way of vlewing this drift is that although a new set of the calculations we did in our earlier study might show some tendency for Canadian locations to Incur relatively higher transportation costs in servicing the changed U.S. market configuration, this would not change our general conclusion: In servicing the North American market, Ontario and Quebec would face higher transport costs than some U.S. locations, but lower than others--such as the U.S. Paclfic Northwest or Upper Midwest. 1 On the favorable side, manufacturing productivity in Canada has Improved VIs-a-vis the Unfted States over the past decade, as shown in column (6) of Table 3. This productivity improvement is welcome in Canada; but it does tend to reduce the potential gafns from a free trade association. This was the reason for our downward revision of prospective gains (Wonnacott, 1975, PP. 176-178) from free trade to the 7-9\% level. Since there is no evidence of any substantial long-term reduction since in the productivity gap that was used in calculating this earlier 7-9\% figure, it may still be viewed as an (admittedly very rough) estimate of the potential gains available today.

With the westward trend of U.S. industry, a given Canadian tariff tends to slightly increase the cost to Western Canada of continuing to buy the protected manufactures of Ontario and Quebec, thus somewhat strengthening the West's interest in North American free trade. 
Table 3

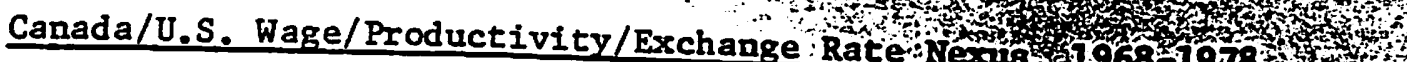

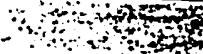

\begin{tabular}{|c|c|c|c|c|c|c|}
\hline & \multirow{3}{*}{$\begin{array}{l}\text { Exchange } \\
\text { rate (value } \\
\text { of Canadian } \\
\text { dollar relative } \\
\text { to U.S. dollar) } \\
\text { (1) }\end{array}$} & \multicolumn{4}{|c|}{ 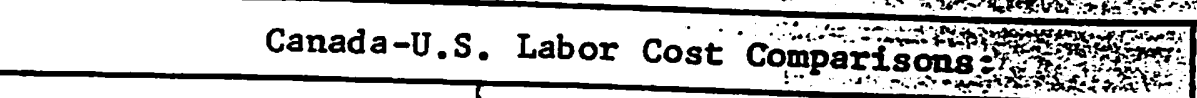 } & \multirow{2}{*}{$\begin{array}{l}\text { Productivity } \\
\text { Comparison } \\
\text { (Can./U.S.) } \\
\text { a }\end{array}$} \\
\hline & & \multicolumn{2}{|c|}{$\begin{array}{c}\text { Hourly } \\
\text { Manufacturing Wages } \\
\text { (in Canadian dollars) }\end{array}$} & \multirow[t]{2}{*}{$\begin{array}{l}\text { Relative Wages } \\
(\text { Can./U.S.) }\end{array}$} & \multirow{2}{*}{ 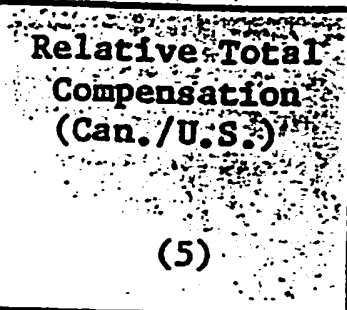 } & \\
\hline & & $\begin{array}{l}\text { Canada } \\
\text { (2) }\end{array}$ & $\begin{array}{c}\text { United States } \\
\text { (3) }\end{array}$ & & & $\begin{array}{c}0 \\
\vdots-2\end{array} \quad(6)$ \\
\hline 1968 & 92.8 & 2.058 & 3.24 & .80 & $.77^{\cdots \cdots}$ & $\because \quad .65 *$ \\
\hline 1969 & 92.9 & 2.79 & 3.44 & .81 & .78 & \\
\hline 1970 & 95.6 & 3.01 & 3.51 & .86 & .81 & \\
\hline 1971 & 99.0 & 3.28 & 3.61 & .91 & .86 & \\
\hline 1972 & 101.0 & 3.54 & 3.78 & .94 & .88 & .73 \\
\hline 1973 & 100.0 & 3.85 & 4.08 & .94 & .88 & .75 \\
\hline 1974 & 102.2 & 4.37 & 4.31 & 1.01 & .94 & .80 \\
\hline $1975 !$ & 98.4 & 5.06 & 4.89 & 1.03 & .95 & .74 \\
\hline $1976 !$ & 101.4 & 5.76 & 5.12 & 1.13 & 1.03 & .75 \\
\hline 1977 & 94.1 & 6.38 & 5.98 & 1.07 & .98 & .76 \\
\hline 1978 & 87.7 & & & & .90 & .78 \\
\hline
\end{tabular}

Sources : Wages and Compensat1on, 1968-77: Recent Trends in Relative Labour Costs: Selected Industries in Canada and the Untted States, Bxecutive Bulletin, The Conference Board in Canada, Oct., 1978, P. 5; and updated estimate for 1978 based on Output per Hour, Hour ly Compensation and Unit Iabour Costs in Manufacturing, Eleven Countrles, 1950-1978, U.S. Department of Iabor (mimeo), October 30, 1979, pp. 2, 11 .

Productivity: Frank, James, Assessing Trends in Canada's Competitive Position (Ottawa, Conference Board in Canada, 1977), p. 60; and U.S. Department of Labor News (Washington, U.S. Bureau of Labor Statistics), July 10, 1979, p. 5. Exchange Rates: Output per Hour and Hourly Compensation..., op. c1t., p. 14,

*This 18 only an approximate figure, since it was calculated for 1967. 
[Note the apparent paradox: Both the favorable change (a closing productivity gap) and the unfavorable one (the southwest movement of U.S. industry) have tended to reduce Canada's potential gain from North American free trade.]

\section{Changes in Canada-U.S. Monetary Variables (Wage Difference and Exchange Rate)}

Our original 1967 book was based on 1958 data, when the industrial wage rate in Canada was substantially less than in the United States. But by 1974 a substantial change had taken place: the Canadian manufactured wage had risen to the U.S. level. (See columns 2, 3 and 4 in Table 3.) Moreover, because the Canadian dollar was roughly at parity with the U.S. dollar, Canadian wages had reached equality with U.S. wages, whether they were measured in domestic dollars, or more appropriately in Canadian dollars (as in Table 3 ).

There then followed a period of 2-3 years during which the Canadian dollar (in column 1) remained at approximate parity while the Canadian wage reached even higher levels relative to the U.S. wage. This apparently was a period of increasing wage/productivity disequilibrium, because the re were no productivity increase in those years to correspond with such large wage increases. (The promising productivity performance in 1974 seems to have been a cyclical blip, reflecting a less serious recession in Canada than in the United States.)

But by 1977 , a correction appeared to be underway; with the exchange depreciation that began in that year, wages in Canada began to fall relative to the United States. Indeed, this is even more evident in the relative compensation figures in column 5 , which we concentrate on hereafter because more recent figures are available, and because this is a better measure of labor costs in any case. (Compensation includes both wages and non-wage benefits such as social security contributions. Because such benefits 
are less in Canada than in the United States, wage comparisons alone tend to overstate the relative height of Canadian labor costs. A comparison of column 5 with column 4 indicates that this discrepancy is becoming increasingly important as time passes.) By 1978, the mid-70's tendency for relative Canadian labor costs (column 5) to outrun relative productivity (column 6) was well on its way to being corrected. (A further $3 \%$ depreciation in the Canadian dollar in 1979 suggests an even further drop in the relative compensation ratio.) By 1978, labor compensation had been brought back into roughly the same relationship to productivity that had prevailed in $1968 .^{1}$

In summary, Canadian locations did indeed lose their wage advantage for a brief period in the mid-70's, before an exchange rate adjustment once again brought wages back down more closely in line with productivity.

These rapid changes have had two important implications for the free trade issue. First, they mean that the method of presenting potential free trade gains should be clarified; and, second, they mean that the role of the exchange rate in the process of adjustment to free trade. deserves emphasis.

of the 7-10.5\% long-run increase in Canadian real GNP from free trade estimated in our earlier study, roughly $4 \%$ was attributed to lower prices for manufactured goods, and the remainder to an increase in

Yore detall on the development of the productivity-wage-exchange rate disequilibrium in the 70's is discussed in Wonnacott (1975), pp. 176-185. 
money incomes--provided that the exchange rate remained unchanged. This way of showing real gains--through a fall in prices, on the one hand, and an Increase in money incomes, on the other (with the exchange rate held constant)--was, we believed, an enlightening and simple way. of considering the effects of free trade. And under the then-prevailing circumstances, it represented a plausible adjustment scenario.

But behind the gains in the form of higher money incomes and lower prices lie real gains, most notably the productivity gains open to Canadian industry as production lines are rationalized. It is this real productivity gain that is important, not the particular way it manifests itself in terms of monetary variables such as wages and prices. Indeed, if one allows exchange rates to change, the real gain may be divided in any proportion between higher money wages and lower prices. For example, with a fall in the canadian dollar, there would be less gain to Canada from lower prices and more gain from higher wages. It follows from this that there is an advantage in terms of precision in measuring the effects of free trade in terms of real productivity gains, rather than monetary ga1ns. Th1s advantage has become particularly important during the last decade when monetary varlables have not only been changing rapidly but have also apparently gone through a period of serious disequilibrium when any monetary measure tends to be misleading. This was the reason that our 1975 recalculation of the gains from free trade (Wonnacott, 1975, Ch. 15, as further detailed below) was based on real, rather than monetary variables. 


\section{A RESPONSE TO CRITICS}

While we have been heartened by the reception of our. 1967 study, it has been subjected to a number of criticisms. The main charges may be listed under six categories: (1) our study is out of date, being based on data more than a decade old; (2) our study suffers from an academic bias towards free trade; (3) our study focuses on bilateral free trade, a proposal which is dominated by multilateral free trade and even by a unilateral Canadian most-favored-nation reduction in tariffs; (4) we have used the EEC as a precedent, but it is not applicable to the North American situation; (5) the adjustment to free trade would be too painful; and (6) bilateral free trade would leave Canadian industry severely truncated; Canadian industry will not be ready for free trade until an industrial strategy has been implemented to rationalize Canadian industry and develop a strong research capability.

Before dealing with the six criticisms in detail, we have two broad observations:

First, our conclusion was that free trade with the United States would have effects in four dimensions: Canadian consumers would benefit in both the short and long run, while Canadian producers would face dislocation costs in the short run, but benefits in the long run (the potential gains from freer access to U.S. markets would more than offset losses in Canada). Since Canadians are both producers and consumers, all four of these dimensions

${ }^{1}$ These are not the only criticisms; in addition there have been a number of traditional criticisms of free trade that existed prior to our 1967 book and were dealt with there (and which, because of space limitations, we cannot answer again. See, for example, the argument that, with free trade our Industry would be unable to compete because the small market in which it operates ensures it will face higher costs.) 
mist be considered. In crltlelalng a bllateral free trade proposal, opponents have often taken a narrow view, concentrating their attention on only one: the short-run effect on producers which, they contend, would be unfavorable. In other words, Instead of providing an overall, four-dimensional evaluation of this policy, they have tended instead to present a brief in support of the producer interest, often further concentrating on just the short-term producer interest.

Second, many of the arguments mounted against free trade with the United States (for example, all the points below except \#3) are no more applicable to bilateral free trade with the United States than to multilateral free trade. Yet critics who vehemently oppose the bilateral approach, are far less concerned about a multilateral one. (There are, of course, good economic reasons why one might prefer a multilateral approach, but they are not the reasons our critics-with the exception of Dauphin (1978)--have typlcally advanced.)

Now for the criticisms in detall: 


\section{Out-of-Date}

This criticism is, of course, formally correct: no empirical study automatically stays up-to-date as time passes--especially one like ours that was based on monetary variables that unexpectedly changed by substantial amounts . This 'out-of-date' criticism was made most forcefully by Britton (1978, pp. 6-8). in what was, as far as we are aware, the only serious empirical criticism of our 1967 study. Britton examined in detail the effects on Canada's competitive position of the fact that. by 1976 the U.S.-Canadian wage differential had disappeared; since Canadian locations no longer had the advantage of lower wages, he was pessimfstic about their ability to attract industry. The problem is that his observations were based on 1976, the year in which Canadian wages had most substantially outrun productivity [see Table 3 . In the Weakest Link (1978, p. 20) Britton recognized that this was a period of wage/ productivity/exchange disequilibrium.] In fact, as Table 3 indicates, 1976 was the last year of such clear disequilibrium; in 1977 the Canadian wage had begun the predictable fall that reduced this disequilibrium by again providing Canadian locations with a wage advantage. Thus Britton's criticism of our study being out of date has itself become out of date. ${ }^{1}$ (Again, as noted earlier, an important conclusion should be drawn from this episode; calculations should focus on real, and not monetary, variables during periods such as the 70's when monetary variables are changing rapidly.)

In short, in the $1960^{\prime} \mathrm{s}$, we measured monetary variables (like wage differences) that would not last forever, but were in a reasonable equilibrium

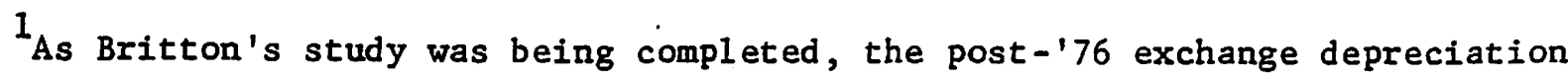
had just begun, and in his conclusion ( $p .16$, published in 1978) he implicitly recognized that this might somewhat temper his pessimistic judgment on free trade. But, because he concentrated on monetary variables rather than real variables (such as productivity)--a trap into which we may have led him--he missed the fundamental source of free-trade gains. 
that had Insted for some time. On the other hand, Britton measured monetary varlables durfing the 70's when they were changing rapldiy and had consequently become relatively unrellable--as subsequent events were to conflrm.

Because by the mid-70's it had become evident that monetary measures had become unrellable, we re-estimated gains from free trade In 1975, as already noted, using real productivity varlables (Wonnacott, 1975, Ch. 15). This conflrmed that much of the potential real income increase we had identifted in 1967 still existed at that later date. Specifically, cur estimate of galns from free trade with the United States (based on 1974

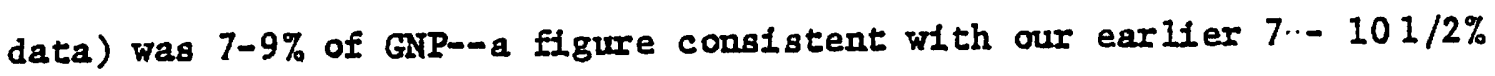
estimate, in view of the productivity gains that had been achleved in the Interim in part because of the Auto Pact ${ }^{I}$ and the Rennedy Round. (As noted already, this $7-9 \%$ estimate still remains roughly valid.)

We now turn to the second and third criticisms, which are contradictory: the second attacks us for making the standard.free-trade argument and assumptions, and the third for not taking the free-trade argument far enough. They cannot both be valid. But one or other may be, so it is necessary to address both.

$1_{\text {Frank }}(1977$, p. 64) estimates that Canadian productivity in the Motor Vehicles and Parts Industry rose approximately $70 \%$ of the U.S. level In 1967 to roughly $100 \%$ of the U.S. level by 1974. 


\section{Textbook Assumptions?}

On a number of occasions, the case for bilateral free trade between

Canada and the United States has been attacked on the ground that it is based on unrealistic assumptions. For example, ${ }^{1}$ Arthur Donner and Fred Lazar (Globe and Mail, October 28, 1975) have argued that:

For success, the free trade model requires a laissez-faire political and economic system (that is, passive governments), truly competitive markets, small, powerless and passive trading firms, unimpeded flows of labor between countries and within national boundaries, free flows of capital, and nonmanaged, flexible exchange rates. Only when these institutional conditions are met, will the participants in international trade experience any improvements in their real standards of living.

It is hard to belleve that people tratned in economics could make such a statement, because it is so obviously incorrect. The assumptions Donner and Lazar 11st have never held at any time or any place. According to their argument, it follows that there could never have been anywhere, at any time in history, any gain from free trade; not by countries in the EEC, nor by states within the United States, nor by provinces in Canada, ${ }^{2}$ Surely

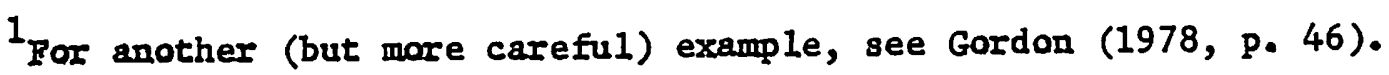

${ }^{2}$ Although he is more careful and limited than Donner and Lazar, Gorḍon (1978, p. 56) asks a sweeping rhetorical question demanding the wrong (negative) answer. "... where in history can one point to a comparatively undeveloped country that has improved its comparative industrial performance through a policy of free trade?" There are, of course, many correct positive answers: for example, Italy in the EEC. (When it joined the EEC, Italy was less industrially advanced than Canada is now.) Or we might cite the Irish Republic, with its recent burst of industrial development; or the now-industrialized states of the U.S. Western Lakes region, which were raw frontier when they came part of the "customs union" formed by the joining together of the American states in the late 18 th century. 
Donner and Iazar could not have meant this 11terally. 1

The charge that free trade gains depend totally on perfectly competitive assumptions is unfounded; ${ }^{2}$ so too is the charge that we based our anslysis on such assumptions. We are astontshed by this

1 Their conclusion is incorrect, even if they had spectfled the free trade model correctly. But they did not; 1t does not require the assumption that factors are moblle between countries.

2 The perfectly competitive assumption is not the only point on which the free trade case is alleged to rest on extreme assumptions, when in fact it does not.

For example, Ritchie (1978, pp. 373-74) states that the case for free trade rests on two propositions, one of which is that the integration of North America would "raise factor productivity and thereby lower unit costs țo USA levels...." But all productivity differences do not have to disappear. It is true, of course, that the more Canadian productivity were to remain below that in the United States after free trade, the weaker is the case for free trade. But if, say, half the differences were to disappear, the economic case for free trade would still be a strong one. Indeed, in estimating Canadian gains from a free trade association, we argued (1967, p. 300) that only part of the productivity gap would be closed over the planning time horizon.

Notice that the Ritchie criticism cited above cannot be valid because it implies that gains could not be realized by any free trade partner that remained less affluent (productive) than the others. For example, it implies that Italy has gained nothing from the EEC because its productivity remains below Germany's--yet Italy does indeed enjoy gains. 
criticism, ${ }^{1}$ because it shows how unfamillar our critics are with what we wrote. $^{2}$ True, our study did on ccasion rely on some of the theoretical

The implication that empirical studies should not rely on competitive assumptions is surprising for another reason as well. $90 \%$ of the empirical research in economics is based on competitive assumptions. (This is equaliy true of back-of-the-envelope calculations using supply and demand curves, and. large econometric models based on complicated supply and demand equations.) While no one would argue that $\underline{\text { all }}$ of these studies are worthwhile, critics who ipso facto disqualify. any study that is based on competitive assumptions are implying that none of these studies has been worthwile.

${ }^{2}$ Perfect competition is not the only point on which our critics misinterpret what we said. For example, Gordon states (1978, p. 49) that "[the Wonnacotts'] position is that a change in foreign trade and employment mix of output that replaced a laborer with an engineer does not increase income." We would never make such a statement: When people switch into jobs with a higher salary, their incomes of course go up, and the presumption is that real GNP also rises. (It does not have to rise. If engineers are paid out of transfers from consumers associated with higher protection and higher prices, then real GNP may not r1se. To use another example, if we keep forelgn technology out, and subsidize our engineers to reinvent the wheel, those going into engineering may enfoy a high income, while the population as a whole has to take an 1ncome cut. But these are speclal cases; the general presumition 18 that a redirection of employment toward high-income occupations will increase real GNP. Indeed, th1s is one of the major arguments for education.)

Readers should be warned: Statements Gordon attributes to us should be carefully checked--not an easy task since he frequently gives no references. 
apparatus of competition. (For example, we wrote of demand curves and of changes In consumers' surplus, which 1mply--reasonably we belleve-that consumers generally take prices as given.) But our major conclusion--that free trade would bring a substantial galn to Canada-was not based on competitive assumptions. (Indeed, It is not clear how any estrmate that 1mvolved simply adding up the supply-demand triangles of perfectly competitive welfare economics could yield free trade gains anywhere near our range of $7-10.5 \%$ of GNP.) Instead, we emphasized the importance of potential economies of scale that had not yet been achieved in Canada; that is, we emphasized precisely those features of the Canadian economy that are incompatible with perfect competition. Thus our biggest innovation was precisely this departure from the competitive textbook model. (Indeed, influenced by earlier triangular welfare studies, we were surprised that the estimated costs of protection to Canada were turning out to be so large.)

Another closely related variant of this argument that free trade benefits depend on perfect competition is that a substantial proportion of Canada's international transactions are being done by MNE's, whose decisions on what to buy, sell, export, import and where to locate are not completely predictable; since they may be sensitive to pressures from the U.S. government, in any move to free trade the Canadian interest may not be as well served as it would be if the firms operating in Canada were Canadian owned. The basic problem with this argument is that it implicitly involves a comparison of a protected world without MNE's to a free trade world with MNE's; but this is not the choice Canadians face. ${ }^{1}$ MNE's are part

$1_{\text {This unjustified comparison is also embedded in a rather amusing recent }}$ analogy that has been going the rounds: Moving to free trade in a MNE world is like putting your affairs in a divorce proceeding in the hands of your 
of the Canadian scene, whether we have protection or liberalized trade. The question is: In that setting, what are the benefits and costs of free trade? Are there any reasons why the existence of MNE's would destroy or seriously damage the case for tree trade?

In our view, it is not even clear that the existence of MNE's even weakens the case for free trade, let alone destroys it. It is sometimes contended that MNE's make the process of adjustment more difficult because they can more easily move out of Canada than can small purely domestic firms. (Notice that this criticism of MNE's holds for Canadian, as well as foreign, MNE's.) But such a move would result in a depreciation in the Canadian dollar that would deter any general exodus--provided the MNE's decisions do not become substantially detached from the pursult of profit. (This is of course the same assumption that is made about perfectly competitive firms, whose behavior also would otherwise become unpredictable.) And MNE's make the adjustment process easier because they would solve one of the most difficult problems Canadians would face: how to sell their more specialized, high volume products in foreign countries: Such products manufactured by subsidiaries in Canada

spouse's lawyer. But this analogy disintegrates under close inspection:

The lawyer to retain is a very important decision if one is contemplating divorce; but whether or not to have MNE's is not a dẹcision facing Canadians who contemplate liberalizing trade--unless the process is to be delayed for a generation or more. The appropriate analogy is this: Going to free trade in a world of MNE's is like deciding to get a divorce when you're not certain you have the best lawyer in town--and when getting a new one will be very time consuming and perhaps leave you no better off than before. 
would be sold in the U.S. by parents using their existing marketing facilities. Thus while Canadian free trade uncertainties may, in some respects, be increased by the existence of $\mathbb{M N E}$ 's, in this marketing respect, uncertainty would be reduced.

A second contention is that foreign MNE's would be better able to "exploit Canada" in a world of free trade. We find any charge of exploitation totally unsatisfactory unless a concrete specification is made of who is doing what and to whom. One such specification is that foreign MNE's charge consumers in Canada more than in the U.S. But free trade may well reduce, rather than increase, the power of the $\mathbb{M N E}$ 's to act in this way.

\section{Bilateral Free Trade Dominated by Multilateral or Unilateral Reductions in Trade Barriers?}

We have already recognized the usual superfority of mittlateral over bilateral free trade; this seems to be a matter of relatively little dispute.' However, we are on occasion puzzled by the context in which this criticism of bilateral free trade is made. For example, J. J. Shepherd, Vice-Chairman of

${ }^{1}$ However, a bilateral arrangement does have one important attraction: it may be easier to negotiate. (Because it is negotiated with only one other partner, it may be possible to arrange a better set of transitional safeguards, sequencing of tariff cuts, and, most important, progress in reducing NTB's.) 
the Science Council of Canada, introduced a speech (1978, p. 1) with the . declaration of his

personal position on the notion of a North American Common Market. I My view is simply that the proposition is essentially protectionist in that it would tend to inhibit the development of genuine free trade between all nations.

The puzzling part of this statement is how it fits into the rest of Shepherd's paper. One would think that Shepherd is in favor of multilateral free trade from this statement. But that is scarcely borne out by the rest of his paper where he argues for an industrial strategy to maintain "Canada as a 'Work Against Nature'" (p. 16). If Canada is indeed a work against nature that needs shoring up by an industrial strategy, then it will face the same sort of problems under multilateral free trade as under bilateral free trade. 2 The National Policy position--that Canadian manufacturing should be protected (either by tariffs alone, or--as recommended more recently--by a broader

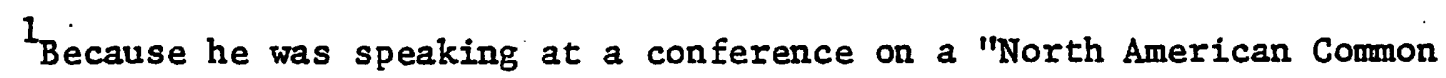
Market", it is not surprising that Shepherd talked of a common market rather than a free trade area. However, it is a free trade area that is usually considered (except, perhaps, by Gerry Brown or John Connally). But Gordon (1968, p. 54) does use the straw man of a customs union, and belabors precisely those characteristics that are not found in a free trade area. He seems unaware of how a custans union and a free trade area differ.

${ }^{2}$ Indeed, even greater problems. From the point of view of Canadian industry, bilateral free trade offers two advantages that multilateral free trade does not: (1) Canadian industry would have to face less competition in Canada from third country imports, and (2) it would receive preferential treatment in the U.S. market vis-à-vis third country imports. (Although 
"industrial strategy") represents a viewpoint that has a long tradition (although we happen to disagree with much of it). National Policy should be defended on its own merits, and not obscured in a smokescreen about genuine free trade among all nations.

More consistent are the free trade views of Roma Dauphin (1978). In particular, Dauphin is concerned with the question of whether bilateral free trade with the United States would be better or worse than unilateral free trade (UFT); that is, a unilateral reduction or elimination of tariffs by Canada. Working from the "modern theory" of C. A. Cooper and B. F. Massell (1965), Dauphin (1968, especially pp. 115-116) argues that UFT is superior to a free trade area. He therefore dismisses a free trade area from further consideration, and concentrates his efforts on the effects of UFT. The problem is that Dauphin begins with an incorrect theory that may be traced back to Harry Johnson (1965) and, especially to Cooper and Massel1 (1965). Because we explain the shortcomings of this theory elsewhere (Wonnacott and Wonnacott, 1979), we nate only the highlights here. In arriving at the conclusion that unilateral free trade can provide at least as many economic benefits as reciprocal tariff reduction, Cooper and Massell ignore the _effects of foreign tariffs. But getting down foreign tariffs (i.e., partners' tariffs) is

bilateral free trade might be preferred by Canadian industry, it does not follow that it would be preferred economically by the nation as a whole; multilateral free trade,-with its cheap imports from third countries, would be preferred by Canadian consumers.) 
precisely the benefit that a free trade area provides that UFT does not. ${ }^{1}$ In other words, Cooper and Massell conclude that a free trade area cannot provide any special benefits because they ignore the one special benefit that a free trade area can provide. ${ }^{2}$

4. Can the EEC be considered a precedent? Isn't North America quite different from Europe?

Of course precedents. never fit exactly. However, unless we wish to abandom the study of economic history and comparative systems altogether, it is still reasonable to examine existing precedents and ask "Do the respects in which precedents don't fit the Canadian case strengthen or weaken their

${ }^{1}$ In our study $(1967$, p. 300), we

estimated that the benefits to Canada of getting down the U.S. tariff would substantially exceed the benefits of removing the Canadian tariff against U.S. goods.

Recently, Berglas (1979) has shown that unilateral tariff reductions dominate a reciprocal preferential arrangement in a model which recognizes the importance of partners' tariff elimination. The inadequacies of this more complex unilateral argument are explained elsewhere (Wonnacott and Wonnacott, 1979). Briefly, the dominance of unilateral tariff reductions shown in Berglas' article disappears when there are tariffs or transportation costs in trading with outside countries. 
message for Canada?" A common suggestion has been that Canada would do less well than a typical EEC participant because one trading partner would be the United States, which is more dominant in North America than any single country is in Europe: The United States is big, wealthy, and owns much of Canadian industry.

(a) Would U.S. Wealth and Owner ship in Canada Make it a Less Attractive Partner?

It is far from clear that these characteristics necessarily make the United States a less attractive partner, as frequently assumed. For example, U.S. ownership in Canada offers one substantial advantage:

It makes the rationalization of Canadian industry easier. It would reduce one of the major adjustment problems producers in Canada would face: How to sell their rationalized, specialized output in the U.S. market. A Canadian subsidiary would have less problem than a Canadian-owned company, since the subsidiary's output would automatically be sold in the United States (auto industry style) through the already-established marketing facilities of the U.S. parent. Moreover, much of the production of U.S. subsidiaries in Canada is already designed for the broad North American market. Nor is U.S. wealth necessarily a disadvantage. In fact, there is a strong prior expectation that greater gains may be found by trading with a wealthy, high-income country than a poor one with limited demand for our goods.

(b) Is Bigness in a Partner Necessarily Bad? Some Economic Observations

A large proportion of the gains from trade go to the smaller country, even in the traditional (constant or increasing cost) theory. The reason is that trade allows a country to achieve gains by exchanging goods at international price ratios that differ from the domestic price ratios it would 
otherwise have in isolation. And the larger the country, the more its. domestic price w111 influence world price (1.e., price between partners); in other words, the less it will have to gain from trade. This conclusion--that economically a small country may acquire more relative benefit from-free trade that a large country--is so counter-intultive (and so contrary to the predominant viewpoint in international forums such as the United Nations) that it may be reinforced by a.hypothetical example. Suppose that the state of Delaware were to leave the: United States, and as a result tariff barriers were to be created between Delaware and the remaining United States. Whose incomes would suffer, Delaware's or the rest of the country's? The answer: Delaware's. But the same would be true if we had picked any other single state, such as Michigan, Florida, California, or Illinois. This then confirms our conciusion that small economic unfts have the most to gain relatively from unrestricted access to "forefgn" markets. ${ }^{1}$ [One of course must be careful with such an analogy: Delaware

${ }^{1}$ Notide that the proposition that an individual state has more to gain from the U.S. "free trade area" than the collection of the other 49 states tells us little or nothing about "fairness". Specifically, we can't conclude that Delaware (or Michigan, or...) is taking. unfair advantage of the other 49 states when it stays in the Union and keeps most of the bilateral gain; clearly each of the states cannot be taking advantage of the other 49 by staying in the Union. In a somewhat similar way, it would be by no means "unfair" for Canada to get the lion's share of the gain in the event of a free trade arrangement with the United States. 
(or Michigan, or Illinois, or...) are already part of a "customs union" with the other states, and have therefore adjusted to open borders, whereas Canada would have to adjust to any free trade arrangement. And clearly the implications of political union and a free trade association are quite different. But the main point nevertheless remains: the smaller unit frequently gets a more than proportionate share of the economic gains.]

This hypothetical question about Delaware is given added force by the existence of economies of scale. With such economies, the potential gains to a small partner become larger, although greater uncertainties arise because results are hard to predict once the increasing costs/perfect competition assumption is discarded. 'We know, however, that when economies of scale are introduced, the gain to the two trading partners together is increased; at least one country has a big gain to reap. (It is disappointing that the lack of precision in the economies-of-scale analysis has led to such a widespread dismissal of this case. ${ }^{2}$ There often seems to be more 1nterest in

${ }^{1}$ As MeIvin (1969) has pointed out, in the face of economies of scale the terms of trade are no longer determinate and it is therefore possible that one country will end up an overall loser from free trade.

2 Any general treatise of international trade theory typically involves one well chosen, delicate sentence recognizing the potential importance of internal economies of scale, but then rejecting them completely from any further consideration. See, for example, R. Shone (1972, p. 85) who dismisses internal economies of scale on the ground that they "would lead to a single producer and are of little theoretical interest." . 
the precise, clean division of a small increasing-cost gain than in the messy division of a large economies-of-scale gain.)

There is a presumption that, in the event of free trade, the smaller country will be the one to reap the large gains from economies of scale, as we argued in our 1967 book. After all, the large country may allready have captured most of the available economies of scale; the smaller country has a large new market opened to it. Skepticism about the smaller country's gain presumably rests on the possibility that the larger country will use its bargaining power to capture the lion's share of the gains.

(c) Is Bigness in a Partner Necessarily Bad? The Problems of Negotiating with the United States

The possible difficulty in bargaining with a single large partner is what makes the Canadian situation different from that of a European country; for example, Holland or Sweden deal with a number of EEC partners, none of which is predominant. This indeed could raise two particular problems for Canada not faced by European countries. First, the focus of economic policymaking in North America would continue to be in Washington, rather than a compromise center in a smaller country (Brussels). The desire to maintain some commercial policy decision-making in Ottawa (namely, Canadian tariffs on imports from third countries) is an important reason why the North American discussion is almost exclusively in terms of a free trade association rather than a customs union. (An economic motive--the desire to minimize trade diversion--is another.) Thus, if we look for a European precedent for Canada, Sweden would seem to be the best example: The Swedes are not part of the Common Market; Instead, they have 
negotiated a free trade arrangement with the EEC. (Incidentally, there are a number of reasons (Wonnacott, 1975, Ch. 12 ) why Sweden-EEC appears to be the most appropriate precedent for Canadians to consider: Sweden is not only small relative to the EEC; it also has substantial natural resources, and a strong desire to remain politically independent. of course, as already noted, no precedent fits exactly; for example, Sweden has far less foreign ownership than Canada.]

The second particular problem is the vulnerability of Canada to a blundering or designing United States; a single powerful partner could presumably do harm which Europeans need not fear with their more diffuse power structure. In our view, the U.S. Is less likely to damage Canada by design than by blunder--in the form of a precipitous reaction to current problems. The 1971 import surcharge is an example, which incidentally, 11lustrates how much U.S. blunders can hurt Canada, with or without an FTA. Indeed it is not clear that an FTA would Increase the damage to Canada of a U.S. blunder. For example, in an FTA Canada would have a recognized claim to special treatment. IIf there had been an FTA in 1971, Canadian exports would have been tariff free, and therefore, automatically exempt from the surcharge--as was the case in autos; Indeed, Canadian exporters would have benefitted from these U.S. surcharges, because of the increased preferences they would have provided vis-a-vis third country producers. Moreover, an FTA might clear up a source of U.S. aggravation with Canada; namely, attltudes regarding the "special relationship." Because of its close ties and vulnerability, Canada traditionally claims and often receives preferential treatment--e.g., in capital controls or beef import restraints. But, on the Canadian side, the close ties are considered grounds for (admittedly not very effective) "third option" programs to divert trade to third countries: that is, to discriminate against the United States. It is not altogether surprising that Canadian appeals for a special relationship sometimes meet a cool reception in Washington.] 


\section{(d) Would an FTA Jeopardize our Political Independence?}

It would be one thing for the United States to damage Canada in error; it would be quite another for the United States to damage Canada--in particular, damage Canada's political independence--by design. In the "Third Option" paper (Sharpe, 1972) argued that a bilateral free trade arrangement with the United States would be an irreversible step; once Canadian industry is reorganized to take advantage of free access into the U.S. market, loss of that access would involve extremely high sunk costs for Canada. The United States could thus use the threat of reducing access to its market to inhibit Canadian independence in other areas. However, Canada's bargaining position may not be as weak as this implies: True, the United States hold Canadian markets "hostage" even without a free trade arrangement, but to a much greater degree with one. But Canada holds potential hostages as well: energy supplies and bIllions of dollars of U.S. investment, to name but two. (Thus, for example, a U.S. threat to change Canada's access to the U.S. market could be countered by a Canadian reconsideration of the tax treatment of U.S. firms in Canada.) But in many other areas as well the United States has a strong interest in keeping relations with Canada amicable: the United States has an interest in a prosperous Canadian market; the United States benefits from access to natural resources such as base metals and hydro power; and the United States has an interest in keeping open the possibility of special arrangements with Canada, e.g., a pipeline across Western Canada.) It is sometimes assumed that all the high cards are in the hands of the biggest economic players; but this is not 
necessarily sol--as can easily be confirmed by a brief consideration of the bargaining power of, say, Kuwait.

\section{(e) Concluding Observat1 ons}

Canada has and will continue to have particular problems because of its role as the smaller fish in the North American pond. Numerous problems would undoubtedly arise in negotiation of an FTA which would test the patience of Canada (and the United States). But the issues are not all one-sided. Indeed, there are some advantages in dealing with a single partner like the United States; when the United States agrees to a decision, it cannot be disregarded by New York state (the way, say, France sometimes disregards EEC decisions.) Moreover, the United States can actually make hard decisions (sometimes). In the EEC, with its diffused structure and need for unanimity, there seems to be little hope of dealing with some difficult problems, most notably its bizarre Common Agricultural Program. Thus the EEC precedent is only partially applicable to North America. The most relevant precedent is Sweden, with its free trade association with the EEC.

\footnotetext{
${ }^{1}$ For more detail on the Canadian-U.S. bargaining situation, see Wonnacott, 1975, pp. 96 - 101.
} 


\section{Adjustment Too Painful?}

We have a great deal of sympathy for Canadian producers who want to avoid what the British call the "cold shower"--the sudden exposire to a more demanding level of competition. ${ }^{1}$.How serious would the adjustment be? The answer, in part, depends on how fast tariff cuts are introduced: If tariffs are eliminated overnight (as many critics unrealistically assume), the adjustment could be a very painful one indeed. But that's not what we suggested, nor the way it is normally done. If tariffs are instead eliminated over, say, a 10 year sequence, there is no reason to be so pessimistic. (This is especially true if the lower U.S. tariff can be negotiated down more quickly than the Canadian tariff, to give Canadian industry the temporary boost of free access to the U.S. market along with continued protection at home.) Indeed, it is not clear that, given the relatively low tariffs that have already been achieved in the Tokyo Round, such phased-out tariff cuts would even be much noticed in a world of flexible exchange rates. Consider two specific policies that might be introduced to minimize the short-run impact: First, when there is a short-term decrease in the value of the Canadian dollar, the next scheduled tariff cut could be introduced. In this way, the buffering effect of the exchange rate on Canadian industry could be exploited to the full. (Of course, pressure from tariff cuts would be

$1_{\text {Thls }}$ is especially true of the subset of Canadian producers who have built up a business by doing the best they could in a restricted, protected Canadian market and who now find that these conditions are changing. Responses must now accordingly change, and this is often difficult to do. But to a substantial degree, changing conditions are overtaking canadian business in any case-whether or not we pursue a bllateral arrangement wi.th the United States. 
brought to bear on Canadian industry; but this would occur only when there were short-term increases in the value of the Canadian dollar. ${ }^{1}$ )

Second, special treatment might be afforded to textiles, clothing and footwear. One reason is that the greatest problems of adjustment occur in these sectors: They employ workers who tend to be old, unskilled, female and resident in depressed areas. Moreover, because they are labor intensive, and consequently have great voting power, they are able to mount strong political pressure. What speclal treatment should they be given? One possibility would be simply to.ask these Industries whether or not they wanted to be included In a North American free trade area. If they say yes, then that would remove their grounds for objection. If they say no, then exclude them. Their major problem is competition from outside North America, and the policy we take in this regard (along with any associated adjustment problems) could be kept separate from the negotiation of a North American free trade area.

of course, even if we make such special efforts, we stili cannot, in the flnal analysis, foresee the future; we don't know for certain how severe the adjustment to a free trade area might be. 2 But there are two additional reasons for expecting it to be less

IOne might consider further buffering by the imposition of Swedish/ EEC type "trigger points" that might be temporarily invoked if imports from partner were to grow more rapidly than some prespecified rate. 
severe than critics anticipate. First, it seems unlikely to us that, even if we start now, we can initiate, plan, negotiate and begin to cut tariffs much before 1988, the date at which we will have finally digested the Tokyo Round cuts. ${ }^{1}$ so a 10 year phasing out of tariffs is likely, at best, to be concentrated in the decade of the 90 's, rather than the 80 's. Thus trade liberalization does not mean huge sunk capital costs and relocation of labor as a result of the reorganization of industry; instead it means planning now for the most efficient design of the next generation of capital replacement in the $80^{\prime}$ s and $90^{\prime} \mathrm{s}$. .

Second, existing precedents suggest that reducing tariffs involves less dislocation than expected--to a substantial degree because specialization tends to occur not between sectors--in fact, not even between industries--but rather within industries. Our original study (1967, p. 336) suggested that this would be the case; we found it exceedingly difficult to determine which

${ }^{1}$ It is, of course, possible that bilateral or miltilateral free trade arrangements in specific single industrles might be undertaken concurrently with the Tokyo Round cuts. But it is hard to see a general across-the-board free trade arrangement occurring this quickly. 
broad sectors would expand, and which decline. In other words, we couldn't find a clear pattern of specialization between industries. (For detail on the within-industry specialization that has occurred in Europe, see Balassa (1966) and Grubel (1967); and for further evidence for expecting a similar pattern in Canada, see Williams (1973).

\section{Will Free Trade Leave Canadian Industry Truncated?}

This criticism has come from Science Council authors, whose diagnosis and prescription for curing Canada's $R$ malaise is dealt with in detail in another paper (Wonnacott and Wonnacott, 1980). We add only a few brief observations here.

The answer to the above question of the critics is: "Yes, in many cases free trade will leave Canadian industry truncated." Free trade in automobiles has not resulted in a well-rounded automobile industry in Canada; research and development operations are concentrated in the United States. However, this fact in itself does not make a case against the automobile agreement; or, more broadly, against a general free-trade arrangement with the United States. The important points are how free trade would affect research and development, and how gains or losses in this respect balance against other gains or losses.

It seems likely that there would be certain types of white collar or design jobs lost in Canada, similar to the jobs involved in minor changes in American-designed cars, or in different paint techniques that have been lost as a result of the auto pact (Reisman, 1978). Moreover, with free trade and larger-scale production in Canada, plant design and organization would more closely approximate that in the United States, and some jobs in Canada in the scheduling-design fields are likely to be lost. Finally, some subsidiary head offices may be cut back 
or eliminated as some U.S. producers supply the Canadian market directly. In such cases, there would be a loss to Canada in terms of high-income jobs and, some would add, the cultural and social advantages of having a group of senior corporate personnel in a community. But this is only part of the story. The question remains: Are the salaries in such jobs now being paid for by Canadian consumers in the form of higher prices? If so, is the implicit subsidy worth it? The answer may be yes or no (indeed everyone may answer this question differently). But even if the answer is yes, it is only part of the story. Under free trade, larger markets would be opened to Canadian producers, and with larger markets would come improved prospects for developing Canadian-based international corporations in some lines. With these would come high-income management jobs. In short, free trade would bring the loss of high-income jobs in Canadian subsidiaries, but eventually the potential gain of high-income jobs in head offices of new Canadian export-oriented corporations.

There is a related consideration that has been given much emphasis in recent discussions of industrial strategy: The question of research and development on the "frontiers of knowledge" in electronics, advanced product design, and so on. Here Canada does not now get its "fair share".of North American research and development--nor is there any guarantee that it would under free trade. Because of the obvious advantages of agglomeration (scientists benefit from talking to one another), $R$ \& $D$ tends to occur in clusters--specifically in the United States around Boston, Chicago and Palo Alto. Thus most regions in the United States do not receive a "fair share" of RAD (if fair share is taken to mean some sort of average ratio of research workers to production workers). California has much more than its fair share of electronics R\&D (especially in the Palto Alto area), but less than its fair share of automobile $R \& D$. The U.S. middle Atlantic region 
likewise has less than its "fair share" of automotive R\&D, but more than its "fair share" of chemical research.

If we are to define a truncated industry as one which doesn't get its "fair share" of R\&D, then every region in the United States (and every country in Europe) has a long 1ist of truncated industries. And there will be many truncated industries in Canada--irrespective of the commercial policies followed. Canada simply does not have the resources to do serious $R$ D across the board-whether under free trade or protection. But in a tariff-ridden world, Canadian industry is even further truncated because its market is truncated. Short of heavy subsidies from the taxpayer, a company cannot incur heavy $R$ \& $D$ overhead costs unless it can spread them over a large volume of sales--and without access to foreign markets that sales volume frequently cannot be achieved. (Heavily subsidized $R \& D$ without adequate regard for where the product will be sold is the story of Concorde: The public pays out large sums to develop an unmarketable product.) ${ }^{1}$ It is no surprise that Canadian $R \& D$ success in the past has been in areas of relatively free access to foreign markets, such as minerals. (Moreover, the much-heralded R \& D expenditures of Northern Telecom were to some degree associated with the tariff-free access of a number of its products to the U.S. market.).

${ }^{1}$ Moreover, those who promote such R \& D subsidies seldom adequately estimate the cost to the taxpayer. For example, the Science Council of Canada recommends that we subsidize $R \& D$ directly by grants, and solve the "inadequate market" problem by having all levels of Canadian government impose purchasing preferences ravoring Canadian high-technology output. The cost of neither of these to the Canadian taxpayer is adequately assessed. (For a criticism of the limitations and pitfalls of government purchasing preference policies, see Wonnacott and Wonnacott, 1980, P P . 35-37.) 
In short, the best hope for a Canadian $R$ \& that is not heavily dependent on taxpayer subsidy is to have large Canadian corporations serving international markets, and hence able to afford large R\&D overheads. Free trade opens up this possibility as protection does not.

The Canadian discussion of industrial strategy has focused on the truncation of industry. But any industrial stragegy which fails to include a market-access strategy is itself truncated. ${ }^{1}$

\section{A Criticism the Critics Missed}

One point we did not recognize in our 1967 study was the effect of U.S., as well as the Canadian tariff removal on foreign Investment in Canada. ${ }^{2}$ Whereas removing the Canadian tariff would discourage forelgn investment in Canada, eliminating the U.S. tariff would encourage it. (U.S. tariff removal would make Canada a more attractive location for U.S. firms to service the U.S. market.) There remains some expectation that the net effect of eliminating both tariffs would be a long-run reduction in foreign Investment, because the expected drop in the Canadian capital/output rat1o under free trade (Wonnacott, 1967, pp. 182-188) implies a falling (perhaps eventually disappearing) net requirement in Canada for investment funds from all outside sources. But this long-run expectation is not as strong as our original argument implied. ${ }^{3}$

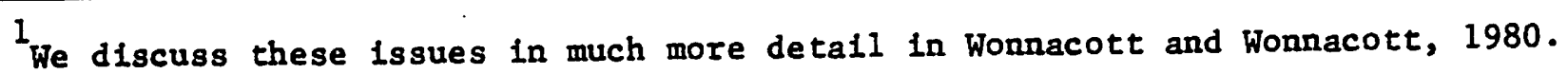

${ }^{2}$ A point we strongly emphasized in the 1967 study was the importance of examining not only the effects of removing the home tariff (as had heretofore been the normal tradition) but also the effects of removing partner's tariff. Thus, it is a bit ironic that the most substantial theoretical point we missed was one of the effects of removing the U.S. tariff.

${ }^{3}$ Moreover, as we noted in our 1967 study, and as others have noted since (e.8., Task Force, 1968, p. 118) the short-run effect of free trade is far from clear; it may even be to increase foreign investment in Canada. The reason is 
IV. CONCLUSIONS

The opponents of free trade--typically non-economists--view its supporters as the captives of traditional economics and insensitive to non-economic arguments. On the other hand, its supporters--typically economists--view its opponents as long on thetoric and short on economic logic. 1 Compounding this has been the opponents' mercantilist preoccupation with evaluating a trade policy in terms of its balance of trade and job creation effects. Recently in some quarters this has become an even more narrow preoccupation: How has a policy--such as the Auto Pact--affected the creation of certain specific types of jobs? (See for example, Shepherd, Globe and Mail, Nov. 21, 1978, p. 7.) This, of course, is a perfectly valid question; but it is not a valid preoccupation. It is inappropriate for scientists and management consultants to put as heavy emphasis on creating jobs in science and management consulting as they sometimes do--unless they are arguing a special case, as

that the reorganization of Canadian production implies financlal reorganization of firms; and it is not clear how much of this would be done with Canadian, and how much with foreign capital. (The answer to this question would depend not only on the degree to which FIRA might resist foreign takeovers, but also on the degree to which the regulations against mergers of Canadian firms might be temporar1ly relaxed--and indeed the degree to which Canadian mergers might temporarily be encouraged through the tax system.)

'See for example, Myron Gordon's view (1978, pp. 54, 55) of exchange depreciation discouraging domestic employment. (Incidentally, on the top of p. 55, he presumes that a Canadian-U.S. free trade area (RFT) would lead to an unfavorable change In Canada's terms of trade. For reasons that this cannot be presumed, see section III-4(b) above.) 
textile workers do when they ask for textile protection. Other questions are also important, such as: "How is production efficiency in Canada affected?" and "How are consumers affected?"

Essentially, the case for free trade has remained the same over the past decade or two, although the gains we measured would be somewhat reduced because of the trade liberalization that has already occurred. These gains would come from increased productivity in manufacturing; how they would manifest themselves in terms of increased money wages and/or a higher value of the Canadian dollar is of second-order consequence and cannot in any case be predicted without a clear view as to how the Canadian exchange rate will be determined.

In our view, more liberalized trade with the United States still holds promise of significant gains, although it is desirable to extend liberalization to as large a group of industrial countries as possible. What is not entirely clear is the best strategy for liberalization: Whether it should be via bilateral industry agreements 1ike autos; or multilateral industry agreements like civil aircraft; or a bilateral free trade agreement with the United States on one hand, and another with Europe (Wonnacott, 1975, pp. 136-142); or some other týpe of initiative. In our view, it is important to recognize that delay involves lost economic opportunities because of dynamic effects we did not consider: Our original study measured only static effects, up to and including the capture of economies of scale through scaling up of plants. Each year Canada delays in fully entering the "major leagues", it seems to 
us, will be a costly one--in terms of leaving Canada further behind in a world of rapidly changing technology. Moreover, in many industries the best opportunity comes only in the era when the industry is born. (In 1965, it was too late for a Canadian-owned car company to break into the newly opened North American market; but it was exactly the right time for a Canadianowned snowmobile company.) Thus the sooner trade is liberalized, the fewer opportunities will be lost to Canadian industry.

Finally, although we understand a natural Canadian reluctance to assume risk; we can see few grounds for the pessimism with which a free trade proposal is sometimes met. The Swedes did not view their free trade arrangement with Europe so pessimistically; nor did the British when they debated membership in the E.E.C. The British case is particularly instructive: Opponents to E.E.C. entry made the same criticism of this move as do the critics of Canada-United States free trade. But they had other arguments in addition.

How could the British, with their ill-controlled wage level, compete with, say, the Germans? Moreover, at the time of this U.K. debate, the prospect was that the E.E.C. would embark on a policy of fixing its exchange rates. And without relief in the form of exchange rate adjustment; what was to prevent Britain (with its then rapidly rising wage) from becoming uncompetitive--the "West Virginia of Europe"? In addition, the EEC's Common Agricultural Policy made entry extremely costly for the British. The trade diversion costs (exacerbated by the much higher level of agricultural protection the British had to embrace, and evident to everyone, in the form of higher food prices) were far greater for the British than they would be for Canadians considering a free trade area with the U.S. (We can think of no major sector of the U.S. economy where domestic prices are anywhere 
nearly so out of line with world prices as are the agricultural prices of the EEC (and where, therefore, the burdens of protectionism are so great.) Moreover, while Britain was forced to embrace this European protectionism, Canada would not, in an FTA, be forced to embrace U.S. protectionism.

In short, there were much weaker grounds for the British to seek entry into the EEC than for Canada to seek a North American free trade area. Yet Britain has gone into the EEC--despite its flaws ${ }^{1}$--while Canada has taken no such initiative in North America.

${ }^{1}$ On the question of whether British entry into the EEC has been a wise move, we feel the jury is still out. To a large degree this depends on what happens to two of the costs the UK faces (that Canada would not have to face in an FTA with the U.S.): the costs of agricultural trade diversion, and the income transfers from the UR to the EEC treasury. For a brief review of differing opinions of the effects of EEC entry on Britain, see the Economist, Jan. 5, 1980, PP. 35-35.

(Oil has been a mixed blessing for Britain: on the one hand it has raised its income, and provided balance of payments strength and a higher pound. But this in turn has increased the competitive pressure on British industry.) 
REFERENCES

Balassa, B. (1966) "Tartff Reductions and Trade in Manufactures," American Ecconomic Review, June: 466-72.

Berglas, Eitan (1979) "Preferential Trading Theory: The n Commodity Case," Journal of Political Economy, April: 315-31.

Britton, John N. H. (1978) "Locational perspectives on free trade for Canada," Canadian Public Policy-Analyse de Politiques, IV:1: 4-19.

Britton, John N. H., and James M. Gilmour, assisted by Mark G. Murphy (1978) The Weakest Link, Background Study 43 (Ottawa: Sclence Council of Canada).

Cooper, C. A. and Masse11, B. F. (1965) "A New Look at Customs Union Theory," Economic Journal, 75, December: $742-47$.

Daly, D. J., B. A. Keys, and E. J. Spence (1968) Scale and Specialization in Canadian Manufacturing (Ottawa: Economic Council of Canada).

Dauphin, Roma (1978) The Impact of Free Irade in Canada (Ottawa: Economic Council of Canada).

Economic Counc1l of Canada (1975) Looking Outward, A New Irade Strategy for Canada (Ottawa: Information Canada).

English, H. E. (1964) Industrial Structure In Canada's Internationàl Competitive Position (Montreal: Canadian Trade Committee).

Frank, James (1977) Assessing Trends in Canada's Competitive Position (Ottawa: Conference Board in Canada).

Gordon, M. J. (1978) "A world scale national corporation industrial strategy," Canadian Public Policy-Analyse de Politique, Winter: 46-56.

Grubel, H. G. (1967) "Intra-1ndustry Specialization and the Pattern of Trade," Canadian Journal of Economics and Political Sclence, August: $374-88$. 

Jenkins, G. P., G. Glenday, J. C. Evans, and C. Montmarquette (1978) In Irade

Adjustment Assistance: The Costs of Adjustment and. Pollcy.Proposals Report submitted to Department of Industry, Trade and Comerce, June, Johnson, H. G. (1965) "An Economic Theory of Protectionism, Tariff Bargaining and the Formation of Customs Unions," Journal of Political Economr; 63, June: $\quad 256-82$.

Leibenstein, H. (1966) "Allocative Efficiency v8 'X-Efficiency'," American. Economic Review, June: $392-415$.

Melvin, J. R. (1969) "Increasing Returns to Scale as. a. Determinant of Trade," Canadian Journal of Economics, II, August.

Reisman, S. (1978) "The Canadian Automotive Industry:- Performance and Proposals for Progress," Inquiry into the Automotive Industry (Ottawa: Information Canada).

Ritchie, G. (1978) "Trade and technology: comments," Canadian Public PolicyAnalyse de Politique, Sumer: $373-378$.

Royal Comission on Corporate Concentration, Report of, Ottawa, Queen's Printer, 1978.

Senate, Standing Committee on Forelgn Affairs (1978) "Canada's Trade Relations With the United States".

Sharp, Mitche11 (1972) "Canadian-U.S. Relations: Options for the Future" (Ottara: Information Canada).

Shone, R. (1972) The Pure Theory of International Irade (London: Macmillan). Task Force on the Structure of Canadian Industry (1968) (Ottawa: Information Canada).

Williams, J. (1976) "Ihe Canadian-U.S. Tariff and Canadian Industry," (Toronto: University of Toronto Press).

Wonnacott, R. J. (1975) Canada's Irade Options (Ottawa: Economic Council of Canada). 


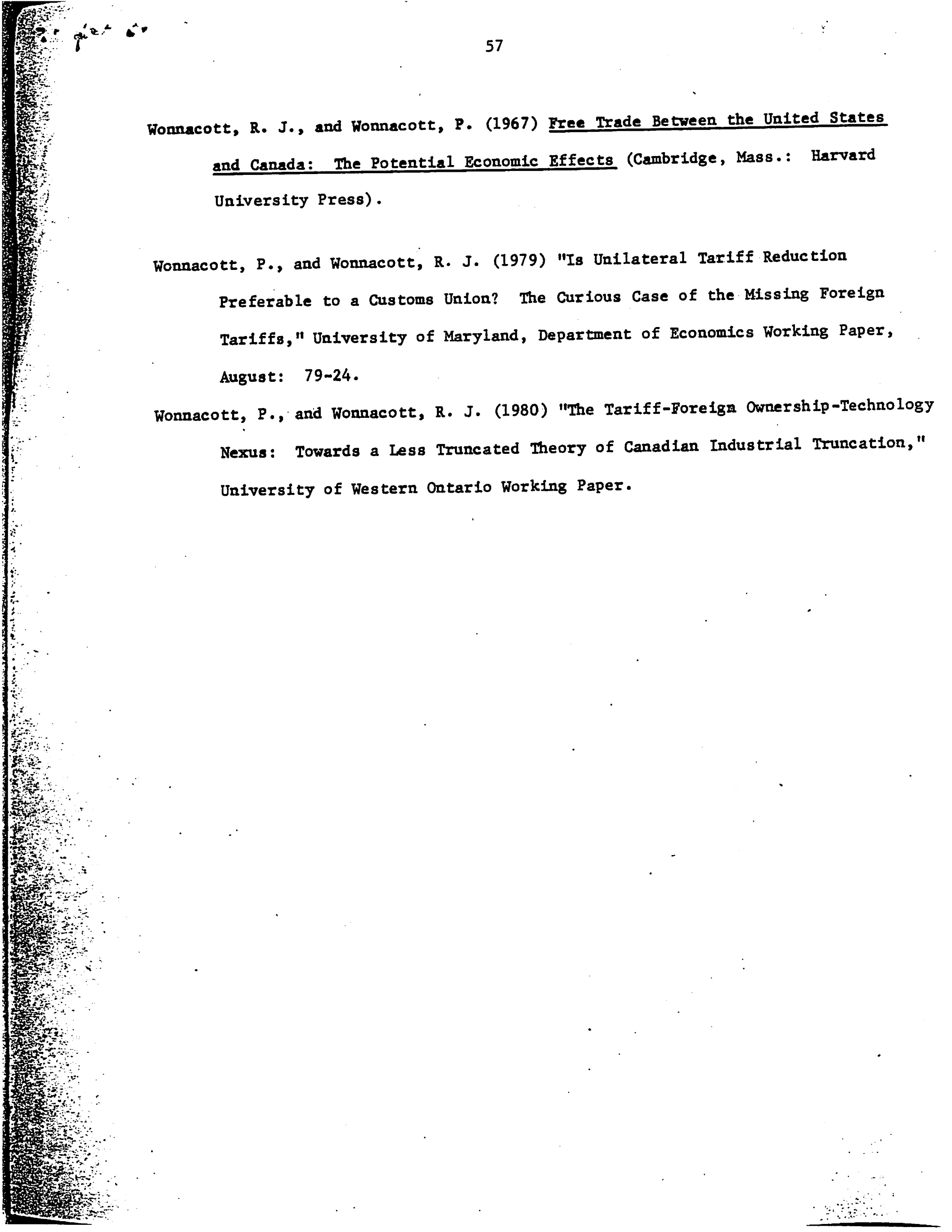

